\title{
THE PROJECT SKOPJE $2014^{1}$ FROM THE PERSPECTIVE OF MASS CULTURE CRITICISM OF F. NIETZSCHE
}

\author{
Vesna STANKOVIĆ PEJNOVIĆ \\ Institute for Political Studies, \\ Svetozara Markovića 38, Belgrade, Serbia \\ E-mail:vesna.stankovic.pejnovic@gmail.com
}

Received 17 September 2014; accepted 7 October 2014

\begin{abstract}
Along with Karl Marx, Friedrich Nietzsche may be considered a great theorist and critic of Art Nouveau, negative life aspects of modern culture considered. Nietzsche developed one of the first sustained critiques of mass culture and society, the state, and bureaucratic discipline that later deeply influenced discourses of Art Nouveau. Nietzsche perceived mass culture central to modern social reality as the forces of decadence and nihilism that undermines the authentic culture and creates a mediocre culture. Nietzsche was "anti-politically" oriented, believing mass politics led to herd conformity, the loss of individuality, producing mass manipulation and homogenization harmful to vital life energy, creativity, and superior individuality. Moreover, Nietzsche thought modern democracy, liberalism, and enlightened social movements contributed regression of "modern man", especially through press and mass culture, focusing on the trivial, superfluous, and sensational, creating homogenization and conformity. The project Skopje 2014 may also be seen from the perspective where the state and political elites are hiding behind culture and national identity trying to build an identity based on culture with no individual but only improvised collectivity. Individual, lost in ideology, system, and environment changes become lost in the collectivity, unsuccessfully trying to find his place, not realizing there is nothing beyond deception.
\end{abstract}

Keywords: Friedrich Nietzsche, individual, Macedonia, mass culture.

\section{Introduction}

The identity gives the individuals to share the world where the individual finds himself and people like him (Schöpflin 2000) this source is not found in the list of references). Fundamental building of the identity of the state of Macedonia is based on

${ }^{1}$ A major project Skopje 2014 for which representatives of government argue to return "aesthetic rebirth" to the city, includes the construction of a range of ancient palaces, monuments, the domes have been planned for the Parliament building (Sobranie), new museum building and several new bridges over the Vardar. The project was conceived as a theme park with dozens of new statues, a sculpture of Alexander the Great 14 meters high, and his father, Philip II of Macedon, the figures of Saints Cyril and Methodius, Saint Clement and Saint Naum, sculptures of Emperor Samuil and Justinian I, horsemen Gotse Delchev and Dame Gruev in the city center. 
the form that homeland is based on culture, not a territorial criterion, which involves requiring beliefs, conviction and the "truth" with a strong need for public opinion to prove Macedonian identity (Stanković Pejnović 2011: 473). The identical attitude toward such identity building holds Nietzsche as a major critic of modernity from the aspects of negation of life that occurs in modern culture. Nietzsche has been in the same way critic of many institutions and values of modern society that are in conflict with powerful energy and creativity systematically holding back the generation of powerful individuals as well as building strong society and culture. In the same way, he is criticizing mass culture and collective, the state, bureaucratic discipline as the foundation for building different perception of modernity. This paper, based on such a view, will demonstrate perspective of Macedonian society through the prism of identity building based on mass culture, evoking past and political identity built on this past. Looking at this phenomenon from the perspective of Nietzsche's philosophy, the author concludes that this policy has the promotion of its own political goals in its mind, while the individual Nietzsche seeks, powerful, strong, and competitive, increasingly disappears.

\section{Nietzsche's criticism of mass culture}

Nietzsche, as the first great philosophical critique of mass culture, has largely influenced and inspired the "right-wingers" Martin Heidegger and Ernst Jünger and "left-wing" followers of the Frankfurt School and Michel Foucault. He was the first to notice mass culture was founded in the processes of modern social reproduction that acquires its most distinct features encouraging massiveness and breaking down individuality, building a mass society, or "herd" and mediocrity. Consequently, he sees the powers of decadence and nihilism in such an emerging society that destroy and humiliate cultural vitality and prevent building an original culture and strong individuals seeking to develop a higher form of culture and society able to emerge strong and energetic individuals seeking self-realization and self-development free from the constraints of social regulation, morality in particular. He believed fresh potential of individual creativity and "higher" form of culture demanded radical socio-cultural changes due to eruption of modern times and prevailing social and political organizations. Nietzsche understands mass culture as destruction of authentic art and development of mediocre culture. Superiority of mass culture is a reflection of humiliation of opinion and culture in contemporary Europe. Such degradation is reflected in the influence of language, style, ideas constantly circulating changing their form, but remaining dominant. Mass culture finds its reflection in mass media, music, alcoholism, politics, and nationalism. Our time is no different to Nietzsche's since our time equally as he has the right to stupidity. Tired working man, easy breathing, with benevolent gaze not responding to anything but letting things flow show pretensions to art... In these times, art has the right to pure stupidity as a kind of relaxation for the mind, wit and soul re-emerging (Nietzsche 1998: 19)... Reflection of his time is present still as the"faceless" continue to have a say. "Our appetites are bigger than reason, and vanity is greater than our appetites" (Nietzsche 1911: 34). Nietzsche 
mocks the feelings of loving kindness, compassion, fairness and our forgiveness in an absurd way, and urges us to "pull ourselves" in a way to raise within ourselves a kind of prophet implying in today's morals and public opinion. It is necessary to replace impersonal with personal, "faceless" with a face (Nietzsche 1998: 23). Nietzsche finds education and the press the most pervasive forms of mass culture as seen today in all mass media, as annihilation of authentic art and development of mediocre culture. Nietzsche considers constant and persistent power and growth of mass culture causes humiliation of thought and art all over Europe. The result is evident even today in the emphasis of aestheticism of ugliness, reversing standards of beauty and putting on a pedestal beauty that does not bear in itself anything artistic, anything that may aspire and create a feeling of higher, and anything to arouse our dormant instincts, in Nietzsche's words. Nietzsche sees politics as a form of mass culture or its reflection or as complement to one another or mass culture in the service of politics. Nietzsche is an "anti-political" thinker and he was convinced that modern mass politics leads to mediocrity conformity and collective building he called herd, loss of individuality, mass manipulation and homogenization. In Thus Spoke Zarathustra, he formed his first critique of the modern state recognizing the state as "cold monster" that is "death to the people" as it lies in all languages and has stolen everything it possessed, and everything it possessed is false. Nietzsche's critique of the state based on the radically individualistic position as Nietzsche suggested isolation from participation and mass society: "Remove from worshiping superfluous... break the windows and jump out... remove from the way of this nasty breath! Remove from the vapors of these human sacrifices!" (Nietzsche 1961: 89). Nietzsche's critique of the state is linked to his critique of mass society and culture that he considers harmful to the vital energy of life, creativity and superior individuality as a modern democracy, liberalism and enlightened social movements contribute to "disappearance of the modern man". Nietzsche considers state and mass culture antagonistic towards true culture while the modern state and mass society are directed towards building mediocrity and cultural backwardness, as well as building mass hysteria in the form of nationalism. In this way, the modern state through politics and society of masses determines the status and hierarchical evaluation, reduces ideals and tastes to the smallest common values, creating mediocre individuals, small and pathetic people seeking invisible revenge, friendly toads with coward cleverness and cramped soul (Nietzsche 1961: 90). Nietzsche believes the press and mass culture forces of degeneration and mediocrity with the intention of directing the focus on trivialities, redundancy, creating homogeneity and conformity. Therefore, Nietzsche's philosophy of culture urges the "revaluation of all values" as "an act of the highest self-reflection of the human species" (Nietzsche 1998: 78), based on the will to power, the capacity for self-development of the human individual. Before starting the re-evaluation it is necessary to have words for something to go beyond that, i.e. it is necessary to call the spade a spade. We had to put a lot of effort to learn external things because it is not as they may seem. Culture is like the icing, like a thin layer in swollen chaos. The development of superior individual demanded overcoming dominant forms of culture and mass society and culture conformity. Nietzsche believes some individuals can create refined self through the 
will to power as the instinct of liberty and is therefore committed to aristocratic individualism and aesthetically shaped person. With the implicit distinction of high and low art, Nietzsche believes authentic art allows "freedom above all else", and what is necessary first, serenity, the serenity of each (Nietzsche 1974: 76). If we had not invented this kind of cult of untrue, we could not withstand an insight into the general falsehood and mendacity or insight into madness and delusion as a condition of knowing or felt existence. What we need in front of ourselves is every wanton, floating, dancing, childish, and blissful art not to lose that freedom over things requested by our ideal. Therefore, we need to be able to stand over morality, but not with timid stiffness as afraid to fall, but to float and play. How may we deprive of art for that, as fools? The roots of the crisis of modern culture, partly lie in the persistent destruction of aesthetic sensibility by the repressive forces of instrumental rationality, social rationalization, mass culture and society in a way art has been increasingly coming to the margins of society. Nietzsche suggests rationalizing forces to be limited by values rooted in aesthetics. Free spirits are needed since they will through experiments, ideas and life create new values and a new culture that will in turn create new superior human beings as Nietzsche seeks a culture that affirms life and creates superior individuals believing culture to be the most powerful way of social and individual transformation. On the one hand, mass culture to him is a reflection of degeneration of culture; on the other hand, it prevents the rise of a better, healthier and more advanced humanity. Nietzsche is famous for his concept of the "great man", a primarily cultural perspective based on the virtues of "higher species" or in other words of artists, poets and other greats of culture. However, their individual prominence alone does not make them significant on a global scale, but their importance stems from their contribution to culture overall (Solomon 2003).

\section{The "struggle" for individual}

Although Nietzsche showed in his writing the spiritual crisis of citizenship of the 19th century, today the crisis has deepened. Nietzsche's relevance confirms him as a prophet of his and our time. Current time, particularly highlighted Nietzschean opposition to mass, pliable culture, i.e. all forms of social stupor and creative genius suppressed in his loneliness. Today, Nietzsche would turn his thesis on the re-evaluation of all values into an imperative, while all he had seen as the decadence of his era, and he sought to diminish, now is even more prominent. Industrial capitalism has grown into a world, or global, faceless scientists and experts have been replaced by even worse - information and banking, while the fashionable culture evolved under the influence of the media to ruthless market culture, and market imperialism grew into planetary occurrence under the name of globalization. Would Nietzsche get into an even more nihilistic gap today between the mindless mass and the cult of the spiritual man who should design the survival of the whole world to match his lifestyle and not just be a slave to totality? Nietzsche actually proved a prophet of nihilism and therefore his work has perhaps greater value today, as a call to reformation of life. As a successor of his thoughts Edmund Husserl saw the collapse of Europe in the mid thirties of the last century in "alienation 
from his own rational sense of life, growing intolerance towards spirituality and fall into barbarism" (Husserl 1970: 121). Nowadays have confirmed the correctness of his thinking. Committing to the postmodern way European opinion went on justification of relativism and anti-rationalism, which opened opportunities more aggressive approach toward spirituality with supporting reform and transformation of the fundamental principles of education. Very often one gets the impression government earnestly and constantly cares for the education of its citizens often indicating the existence of a large number of educational institutions. Yet it is not so because the numbers do not contribute to the improvement of their quality, but involves surplus people without knowledge, but also those who, little by little, determine the spirit of the institution, large in number and their similis simili gaudet instinct. In this totality where man is blindly left to his lifestyle, there is no more space for freedom, it is redundant and serves no purpose (Horkheimer, Adorno 2002; Marcuse 1964). Yet Alexis de Tocqueville warned demolition of traditional structures of European society began with the French Revolution and opened way to social forces that can turn people into a flock of timid and industrious animals that will have nothing of freedom in a democracy, describing a complete mechanism of society totalitarianism. Total power is durable, quiet and elegant slavery, and it does not rely on physical force, but the systematic restriction of human activity. Such authority tends to maintain people in a state of eternal childhood (Tocqueville 2000: 458). The dominant educational systems and educational policy reform may be taken into account just as a function of the encoded technocratic and economic investment in the future. "To rise, is to raise oneself, education, is to educate oneself" (Misgeld, Nicholson 1992: 125).

Similar things Foucault interprets as "taking care of oneself", as we may observe the distinction in the sense of self-education, here in question. According to Nietzsche, the ruling Democratic-utilitarian conception of education does not understand the necessity of an independent status of culture in relation to the welfare of the state or society (Nietzsche 1909b: 89) while education should be in the service of culture, not the state. Reigning reflection of education, and therefore the culture rarely was exactly understood. Its aim is neither the greatest possible happiness of people, nor unfettered development of all his gifts, but creating great work. This misunderstanding has its carrier and further caregiver, embodied in the figure of "educated Philistine" (Nietzsche 1996: 178) who imagines to be the son of the Muses and a man of culture himself" (Nietzsche 1909a: 45) while he is the fruit of a democratic (pseudo)culture, mediocrity, as the product of "popularizing science", i.e. tailoring science to the needs of "mixed audience" or in Nietzsche's words "descent of scholars to their people" (Nietzsche 1909b: 56). Resultant of such education is mediocrity, average, "cartoon education", while education is perceived only as a means of durable life, never as an end in itself. Such an attitude only further deepens the problem: it is self-mediocreted (Nietzsche 2007: 145). An educational constraint of time does not allow maturation for its benefit to govern the immature and to exploit them. There remains a deep sense of hopelessness, hostile to each novelty, an attempt of bravery, free wish, withstand flight into the unknown, allowing imposition only what becomes. But if asked the question of progress of culture as a separate phenomenon, most would answer that progress (national 
or world culture) depends on the direction and the way education of new generations is conducted, and few will wonder what kind of progress, if there has ever been one in principle (Bloch 1963: 145) and in which areas we can say, since we can not remember Ernst Bloch's extraordinary insights about the existence of loss in progress. The goal for each individual must be the necessity of organizing the chaos in them and returning their real needs. One must dare and have confidence in oneself while for shyness one becomes an actor and plays a different role. Historical meaning eradicates the future as it destroys illusions and takes away the atmosphere from existing things, the only place they can live. In modern man next to his pride is his irony over himself, awareness of the necessity of living life in an almost evening mood and fear than nothing of his youthful hopes and power can be saved for the future. There is a cynical excuse it must be as it is now, since this man had to be and against the "must" one must not complain, while his most complete phrase of cynicism is reflected in the fact of modern living, handing over his personality to global processes. Nietzsche sees people, transformed by history into mere abstraction and shadows; no longer prepared to be human, but masked into educated man, scholar, poet, politician (Nietzsche 1909b: 56). Therefore, man should stop deceiving himself since there still has not been so much talk loudly about "free personality", and without personality, let alone free, but only on the fearful twisted universal people whom the pure objectivity fits. The center of Nietzsche's world is an ode to individualism, but also fierce criticism of the institutional culture and the state, and is no wonder Nietzsche is a great inspiration to artists and philosophers, Thomas Mann, August Strindberg, Albert Camus, D. H. Lawrence, Hermann Hesse and Ksaver Šandor Gjalski. Nietzsche's philosophy is a reflection of his desire for philosophy of life that needs to draw a vivid picture of the world and existence, an image in which the individual seeks his adventure of self-realization. In addition, his contempt for the modern society that realizes false, imposed imperatives of happiness, rather than internal ones, received many successors. Although a follower of Arthur Schopenhauer, Nietzsche overcame pessimistic vision of the world by an image of a strong, distinctive genius whose desires constantly drive life, experiments with him, reveling in his own art of living. Common is extreme individualism, conception of philosophy as liberation of the inner life, and not as a personal recovery of knowledge. The individual is the one that has to resist not only external violence, indoctrination and manipulation, but also overcome the lack of culture himself. Unconstruction of identity through the dominant discourse and usually uphold the rule of language and symbols, but to achieve different never fully assimilated meaning of speech, creating a reality that needs to belong to someone else. Moreover, what with the most direct expression of being and the inherent will to live, with individualism? Every aspect of identity unconstruction in society as a whole, although through the model of the modernized civil society leads to a loss of distinctiveness expressed through the principle of negative will for power and as a symptom of the inability of belonging to the Other, which takes place through the centuries of man deterioration and decay of life. The consequence of anthropological imperialism therefore leads to psychologism. Precisely here lies the origin of pessimism, negation of the world of life, death of God, and thus the truly individual in a man, his liberties, himself. Self-overcoming, this great 
Nietzsche's concept, a normative and holistic conception of individuals is inherent, individuals who are committed to the imperative of building complete personality. As an example of such a person Nietzsche sees Johann Wolfgang von Goethe, while he wanted totality and disciplining completely, he created himself. Nietzsche teaches us that we need to look forward and shape the image within ourselves the future should respond to, forgetting the superstition we are epigones. Nietzsche encourages us not to take things for granted and not to succumb to assumptions and remove our rooted beliefs. He dislikes scientists, despises civil servants, those who subordinate culture to institutions, and hates selfishness of entrepreneurs and egoism of the state. He raises libertarian ideals of the Renaissance to the extreme. He sees true philosopher as the artist and a hero, and philosophy as the only asylum tyranny cannot reach. He loves peculiar individuals, separated and different, superman, often misinterpreted as a man who rose from too human in himself and has overcome himself, achieved his freedom. Weight and individual opposed Nietzsche, closely associated with the influence of morality and Christianity while it identifies people and subjected them to a common idea. There is a difference between the Dionysian creator, uncut, original passion, and the Apollonian creator who seeks harmony, outer shape, and does not see the inner being. Nietzsche points out the difference between philosophy as a theory and philosophy of life, immoderate and irrational that overtakes the spirit, representing life in movement and diversity. He believes in new, enlightened culture created only by creative philosophers and artists, finishing the nature, turning its germ in the crown, and not undermine it, in the name of society. Such a task, that will ultimately assume civilization to culture, have recently elected and finally, Nietzsche admits only a strong person, or individual value system. Is this not the reason Nietzsche is again relevant today? If creative geniuses today are the producers of goods which we become inextricably linked, if educators now are computers, and not some astonished truth-loving individuals, if all sorts of celebrities are called revivalists of culture today, was not Nietzsche really a prophet to crisis of creativity? These are so extreme that we think of Nietzsche even harder, more passionate, and more challenging, compared to them. Yet has not this ready-made time cultivated the individual even more agitated, the urge for creativity? Where has life itself gone, which Nietzsche called growth, in a word, or the need to have more? There is victory, without acknowledgment, while what has not been in the media as if never happened. For Nietzsche modernity is only cosmopolitanism of literature, newspapers, forms, tastes and some sort of adjustment to that impression is present. One forgets to agitate, the spontaneity weakens, weakening the strength, will, desires, purposes and resources. Nietzsche in the 19th century, wrote that susceptibility to the training of people increased in a democratic Europe, people who learn easily, who are eager to obey and become herd animals. Who can command finds those who have to listen. Life is one of the key concepts of Nietzsche's philosophy, for to live actually means to survive, or more precisely: outlive the other while he looks at life as an instinct for growth, to endure, to gather forces, for power since where is no will to power, one feels. These life forms, which are the strongest, are more likely to survive than weaker. Will for life, reveals as the will to power, and is expressed in the strength, growth, development, expansion. If it ends in weakness, lack of power or even impot- 
ence instead, then degeneration occurs. How one leads the war against the passions of men and value system? There are no physical violent means, but the war being led only by cunnings, tricks, lies, in short, with spirit. Nietzsche thinks morality is one of the means, serving depraved life, destroying man while he believes that if believing in morals, one condemns life since morality proclaim "plebeian" features as virtues, and "aristocratic" virtues on the other hand one-time as undemocratic and elite. Nietzsche's condemnation of moral is fierce, and what he required of philosophy is overcoming weak i.e. Affirmation of strong will as mortal man is a lower species too immoral, and worse, just a copy, good copy at best - but the measure of his value lies outside him. A man should be judged by the quantum of power and abundance of his will. Active nihilism is defined on the basis of strength that we may recognize the necessity of lies while passive nihilism is pure and simple statement of the fact that most appreciated values lose their value and can be observed through a complete sustainability of life. Nihilism, as the thought of "duration without purpose and direction" in which "we are deceived and at the same time we do not have the strength to not be deceived" is a thought that is the most paralyzing. We are tired since we lost all incentive while we were looking for meaning in the whole event that was not, wasting all our strength, ashamed before ourselves and losing courage eventually. Such a life without direction and purpose inevitably returns, with no end in anything, through the eternal return as the extreme form of nihilism: eternal (meaningless) nothing in its deepest interior of a man who no longer knows where while with him and outside there is just gap with a view reflecting nothing. The mediocre do not feel this conflict and shape the whole "culture", as they see themselves as objective and meaning of the uselessness of modern society. The entire system aimed at weakening the will to power, the sense of pride as individuals and directed toward humility as a denial of life or potentiation of the herd instinct, summed zeros, while being zero is a virtue. Nietzsche warned that nihilism is a psychological condition occurring when individuals become thirsty for admiration and enjoy the collective perception of the highest form of mastery and government where one feels a deep sense of connection and dependence on the infinitely superior whole. The intention is to achieve this not only in Macedonia but also in the entire Western civilization.

\section{Building identity through mass culture}

The project Skopje 2014 is part of, or form of political propaganda under the guise of (re)shaping the identity of the combination of antiquity and the Renaissance the Macedonian society did not have as part of its social-cultural development. The whole world of true being becomes a delusion as the "true", "real" world in which man has lost himself, lost on his honor. The project Skopje 2014 is similar to adaptation of Western models that never existed in this area, and is similar in some ways to today's implementations of the legal acquis of the European Union (simplified as EU) in every country that aspires to become a future member, although the Balkans is the cradle of European civilization. Althought modern architecture lost contact with the user who in its prefabricated spaces felt lonely (Antešević 2013: 485) in this new project individuals also cannot find their space and they felt lonely. 
The critics labeled the project as Antiquisation, referring to the term coined by the historians to explain the Renaissant practice of giving a city the appearance of ancient Rome or Athens. It was not an explanation of a sudden love of the country for the classical poetics, but pointering to the nationalistic myth-building and an attempt to construct a nationalistic superstate (Koteska 2012). The background is disguised political propaganda of unification and the imposition of non-existing collective. Yet Nietzsche ridicules, mocks and scorns the "common spirit", homeland, or in today's language, the collective identity since it is all directed towards crushing individuality. Large "project" of excessive highlighting traditional symbols, the construction of buildings like ancient, intrusive stressing the continuity of today's Macedonia with ancient Macedonia justify building a sense of solidarity, based on the consideration that elements of the identity, the territory, the name, the myth of origin and a common culture (Smith 1986: 201). The ruling structure justifies their megalomaniac project of mass culture by the fact that it is important to highlight the historical legacy that has a crucial role in building national identity, stressing it of great importance while each nation has its own history and experiences that are unique and different from other nations (Buzan 1991: 78). Project Skopje 2014 emphasizes the presence of older strong forms of repression, or new techniques of power availabele to institutional actors (Mattioli 2014: 83). Macedonia is not a parliamentary democracy based on civic principles, while it is not based on the rights and freedoms of citizens, but the rights of ethnic communities. The most severe problems are within the country, and at the same time refer to the fulfillment of the obligations of the Ohrid Agreement. Since the Ohrid Agreement, Macedonian and Albanian political elite have been aimed at defining the legal and political status of the Albanian community, and cultural models (Stanković Pejnović 2010: 236). Optimists believe the state is nearing the final application of this document. Is it the end of the process from "Ohrid Macedonia" to "European Macedonia", only time will tell. Macedonia is still a poor country, which is not able to show real results in any sphere, of weak and ineffective institutions, and the government based on the agreement of the elite of two most prominent ethnic communities. The common interest of all the elites is privileges of power, including opportunities to get rich quick. One of these aspects reflects in the fact that many Macedonians do not oppose often illegally built mosques thus maintaining fragile social harmony. Still, they get angry when an attempt to build some kind of church is shown a major incident. As the new identity founded on the Orthodoxy and evocation of the past (Thiessen 2007: 48). Albanians see the project Skopje 2014, and similar projects, the construction of churches and museums as attempts of "macedonization" demonstration and perceive them as their humiliation, stressing once more the crisis of the collective society. Macedonians, on the contrary, consider Macedonia their "natural" ground and are reluctant to give space to the Albanians, or even believe the Albanians "have occupied physical and imaginary space" (Brown 2000: 234). National identity is a result of confronting requirements based on more or less established requirements and interpretations of historical events as a process founded on group belief in the legitimacy of the claims to the homeland (Stanković Pejnović 2011: 473). The modern state leaves no room for ethnic autonomy, which is in contradiction 
with the new ideology of integration of all citizens into a new national state as the new ideology of political nationalism, which finds its ground in Macedonia located in the project Skopje 2014, requires homogenization of all members of the "national state". Task imposed on Macedonia's political elite, refers to attempt to establish a common identity in an ethnically complex society that has no single political community, as there is political boundaries between Macedonians and Albanians (Laclau, Mouffe 1985: 234). Therefore, the ruling political elite decided to create and shape the identity of the internal cohesion as history and "usable past" are useful for building Macedonian national feeling deep in the past, but also as an instrument of shaping national consciousness and create a sense of unity and loyalty. Every nation needed a unique and honorable "myth" based on the past (Smith 1986: 156). The question of the identity of the state itself has not been resolved, and theoretical solution, which the international community was trying to solve the ethnic conflict introducing ethnic designation in the primary good as a form of implementation of all ethnic minorities in the Macedonian society, has not achieved its full objective in practice. Every day the delicate balance between the two most prominent communities in Macedonia reveals that religion, identity, land and power deeply intertwined. Even in his century Nietzsche pointed out that the tradition was perceived as a fatality studied and recognized as a heritage, and today in the emerging Balkan states tradition has been raised to the cult everyone aspires to. How much is Nietzsche up-to-date testifies his long demonstration that democracy based on a self-deception of many as it tends to depreciate and submit people. The government justifies the project Skopje 2014 with other European cities having churches and monuments in its center, deliberately ignoring the fact that they have been built for centuries and were a reflection of the culture and society that had been shaped in layers for many years. After all the explanations, the project has just been a reflection of the political domination of the Internal Macedonian Revolutionary Organization - Democratic Party for Macedonian National Unity (simplified as VMRO - DPMNE, in Macedonian: Vnatrešna Makedonska Revolucionerna Organizacija - Demokratska Partija za Makedonsko Nacionalno Edinstvo) and coalition with Democratic Union for Integration (simpified as DUI, the largest Albanian political party in Macedonia) which will not be a symbol of integration and bringing people together, but immature and uncreative cultural policy without diplomatic and political vision. Skopje 2014 is obscure evocations of ethnic nationalism in SouthEastern Europe, with intention of the Macedonian government that national identity of the Macedonians not only represents the national independence of the Macedonians (Brunnbauer 2014). Necessary spirit of compromise is not achieved by sudden and imposed decisions and short-term agreements behind closed doors of government agencies. It is necessary to create a society founded on cultural values and ideas of liberty depicting the emotional character of society, sculptures reflecting the evolution of the Macedonian identity, unifying and reflecting the society under different ideologies and systems, with equal pride. The project is also seen as an attempt to distract people's attention from the real problems of unemployment, poverty, infrastructure neglect and delays in approaching the EU and NATO. Moreover, where is the individual himself? Lost in himself, lost or drowned in collectivity trying in vain to find 
his place and himself, not realizing there is nothing behind the deception, and, in Nietzsche's words, all while individuals are willing to bend the will, a cause, the risk itself, to give themselves a goal, escaping any kind of responsibility.

\section{Conclusions}

We are still far from Nietzsche's aspirations to change the world to be able to bear it, where the individual felt responsible. Nietzsche points out the identity is in the nature of both, the conqueror and legislator, but the artist as well. According Nietzsche, our perception of culture depended on anthropocentric and anthropomorphic standpoint. The first is marked as decadence and in its "human too human" form aimed at radical weakening of the will to power, while on the other hand "will to be a unique human being", with its own strength and taking responsibility for his own world of "auto-formation". In Nietzsche's perception, a sense of comfort perception involves an aversion as a challenge to overcome oneself, since the joy of beauty had intensified against feeling ugly. However, ugliness, a rebuke itself, the Greeks found almost a refutation, and sometimes downward development. Ugly is considered a sign and symptom of degeneration. Any sign of exhaustion, discomfort, age, fatigue, any kind of lack of freedom as spasm, paralysis, especially smell, color, form of decay, rot, and in the lightest form of symbolism - all this causes the same reaction, definition "ugly". In Gilles Deleuze's words, in this post-nihilistic upheaval we have come from Heidegger "to be in the world" phase to the stage of "being for the world". "Openness" and therefore "hazards" of very existence has been proven as anthropocentric deficiency. Perceive something means to say yes to while the world and the perception go together always belonging together as a reciprocal thing. Today in postmodernity, one might say Nietzsche was right while we are increasingly forced to vegetative existence in the world, into not feeling of belonging to this world, and finally to realize this world is not for me and we liked different. That is why Nietzsche sees culture as individual fulfillment and hence his reference to cultural values is valid today. You need to learn to look, to learn to think, to learn to speak and write; the goal of all three tasks is the aristocratic culture. Learn to look means to be patient, learn to avoid and cover a case from all aspects while it is the foundation of spiritual development, to have a strong will, to be able to put off the decision while one must respond and follow every impulse. Nietzsche finds the state cold monster that lures many, and posing as a new idol of worship, buys your virtues' glow and proud eyes' looks. A slow suicide of all, which the state called "life", expressed in mass culture as a reflection of submission to the idol, destruction of the individual occurring where the state ends and where a rainbow might be seen. The Skopje 2014 project is an expression of mass culture in the service of policy evoking "the history, understanding the origin and development, and compassion for the past, new rebellious passion of feelings and knowledge" as a reflection of the "cold monster" seeking to build a collectives' and identity aiming to keep us spiders more in its web. The project, carrying only a reflection of the culture or the state, as a cold monster, is hiding behind the symbols of culture that do not evoke the ascent of human, but integrating with difficulties into the collective in the 
name of identity, as well as a pulling the attention from the real social life problems. The idea behind Skopje 2014 is to repeat the old motifs, "as they once were", without the cynical distance, which arguably makes the Project a scary and totalitarian display of power. The project introduced considerable split in the Macedonian national identification with people self-identifying as either belonging to the societies obsessed with history (the government proposal), building national or something "authentic" or building cosmopolitan, or civil society. Skopje 2014, furthermore produced a line of ethnic, gender and class divisions. "Regimes of aesthetics" must be understood in relation to state power. In thise nonrealistic reality, an individual, lost in changes of ideology, system, life circumstances, thus becomes lost in himself, lost or drowned in collectivity trying in vain to find his place and himself, not realizing there is nothing behind the deception, and, in Nietzsche's words, all while individuals are willing to bend the will, a cause, the risk itself, to give themselves a goal, escaping any kind of responsibility.

\section{References}

Antešević, R. 2013. The Influence of Balkan Tradition at the Yugoslav Architecture of the Twentieth Century - Theoretical and Historical Treatise through Review of Selected Chronological-Spatial Examples: Forms of Modernity in Balkan Vernacular Architecture and Its Impact On Modern Architecture, in Bogdanović, R. (Ed.). International Conference and Exhibition on Architecture: Conference Proceedings. Belgrad: STRAND - Sustainable Urban Society Association, 464-483.

Bloch, E. 1963. Tübinger Einleitung in die Philosophie. Frankfurt: Suhrkamp.

Brunnbauer, U. 2014. Das Projekt "Skopje 2014". Oder: Wie ein Land seine Zukunft verbaut. ostBLOG: Ost- und Südosteuropa im Fokus der Wissenschaft. München: Institutes für Ost and Südosteuropaforschung.

Brown, K. 2000. In the Realm of the Double Headed Eagle: Parapolitics in Macedonia, 1994-1999, in Cowan, J. K. (Ed.). Macedonia: The Politics of Identity and Difference. London: Pluto Press, 31-48.

Buzan, B. 1991. People, States \& Fear: An Agenda for International Security Studies in the Post-Cold War Era. Harlow: Longman.

Horkheimer, M.; Adorno, Th. W. 2002. Dialectic of Enlightenment: Philosophical Fragments. Stanford: Stanford University Press.

Husserl, E. 1970. The Crisis of European Sciences and Transcendental Phenomenology. Evanston: Northwestern University Press.

Koteska, J. 2012. Troubles with History: Skopje 2014, ARTMargins [online], [cited 1 August 2014]. Available from Internet: http://www.artmargins.com/index.php/2-articles/655-troubles-withhistory-skopje-2014

Marcuse, H. 1964. One-Dimensional Man: Studies in the Ideology of Advanced Industrial Society. Boston: Beacon Press.

Misgeld, D.; Nicholson, G. (Eds.). 1992. Hans-Georg Gadamer on Education, Poetry, and History: Applied Hermeneutics. Albany, NY: State University of New York Press. 
Mattioli, F. 2014. Regimes of Aesthetics: Competing Performances Surrounding the Skopje 2014 Plan, in Petrović, T. (Ed.). Mirroring Europe: Ideas of Europe and Europeanization in Balkan Societies. Boston: Brill, Leiden, 64-89. http://dx.doi.org/10.1163/9789004275089_005

Laclau, E; Mouffe, Ch. 1985. Hegemony and Socialist Strategy: Towards a Radical Democratic Politics. London, New York: Verso.

Nietzsche, F. 1909a. David Strauss: The Confessor and the Writer, in Nietzsche, F. Thoughts out of Season. Edinburgh: Edinburgh Press, 1-48.

Nietzsche, F. 1909b. On the Uses and Disadvantages of History for Life, in Nietzsche, F. Thoughts out of Season. Edinburgh: Edinburgh Press, 49- 91.

Nietzsche, F. 2007. Ecce Homo. New York: Oxford University Press.

Nietzsche, F. 1996. Human, All Too Human: A Book for Free Spirits. Cambridge: Cambridge University Press.

Nietzsche, F. W. 1911. The Dawn of Day. New York: The Macmillan Company.

Nietzsche, F. 1974. The Gay Science with a Prelude in Rhymes and an Appendix of Songs. New York: Vintage.

Nietzsche, F. 1961. Thus Spoke Zarathustra. Harmondsworth: Penguin Books.

Nietzsche, F. 1998. Twilight of the Idols. New York: Oxford University Press.

Schöpflin, G. 2000. Nations, Identity, Power: The New Politics of Europe. London: C. Hurst \& Co.

Smith, A. D. 1986. The Ethnic Origins of Nations. Oxford: Basil Blackwell.

Solomon, R. C. 2003. Living with Nietzsche: What the Great "Immoralist" Has to Teach Us. New York: Oxford University Press.

Stanković Pejnović, V. 2010. Postaje li Makedonija binacionalna država, Sociološki pregled 44(1): 230-246.

Stanković Pejnović, V. 2011. "Sporan identitet” Makedonije: identitet različitosti, Etnoantroploški problemi 6(2): 471-496.

Thiessen, I. 2007. Waiting for Macedonia: Identity in a Changing World. Toronto: Broadview Press.

Tocqueville, de A. 2000. Democracy in America, and Two Essays on America. Chicago: University of Chicago Press.

\title{
PROJEKTAS SKOPJE 2014 IŠ F. NIETZSCHE'S MASINĖS KULTŪROS KRITICIZMO PERSPEKTYVOS
}

\section{Vesna STANKOVIĆ PEJNOVIĆ}

\begin{abstract}
Santrauka
Greta Karlo Marxo, Friedrichas Nietzsche gali būti vertinamas kaip didis Art Nouveau teoretikas ir kritikas, gilinęsis ị moderniosios kultūros negatyviuosius gyvenimo aspektus. Nietzsche išplètojo masinès kultūros ir visuomenès, valstybès ir biurokratinès disciplinos kritiką, kuri yra bene pirmoji tokia nuosekli kritika, vẻliau turejjusi didelès įtakos Art Nouveau diskursams. Nietzsche ma-
\end{abstract}


sinę kultūrą suprato kaip esminę moderniosios socialinès realybès atžvilgiu kaip dekadanso ir nihilizmo jègą, paveikusią autentiškąją kultūrą ir kuriančią vidutinybių kultūrą. Nietzsche's orientacija buvo ,,antipolitine““ - jis tikejo, esą masinè politika veda link minios konformizmo, individualumo praradimo, produkuoja masinị manipuliavimą ir homogenizavimą, žalojančius vitalinę gyvenimo energiją, kūrybiškumą ir aukščiausiajji individualumą. Be to, Nietzsche manè, kad modernioji demokratija, liberalizmas ir švietejiški socialiniai judejjimai prisidejo prie „moderniojo žmogaus“ regreso, ypač dèl spaudos ir masinès kultūros ịtakos, sutelkiančios ties banalybèmis, nesaikingumu ir jutimiškumu ir produkuojančios homogeniškumą bei konformizmą. Projektas Skopje 2014 taip pat gali būti vertinamas iš tos perspektyvos, kur valstybès ir politinis elitas prisidengia kultūra bei nacionaliniu identitetu, siekdamas sukurti identitetą, kuris būtų grịstas kultūra be individualumo - vien tik improvizuojamu kolektyviškumu. Ideologijoje, sistemoje ir aplinkos permainose nuskandintas individas, bandydamas surasti savąą vietą ir nesuvokdamas, kad nebèra nieko, išskyrus apgaules, buvo kolektyviškumo sunaikintas.

Reikšminiai žodžiai: Friedrichas Nietzsche, individas, Makedonija, masinė kultūra. 